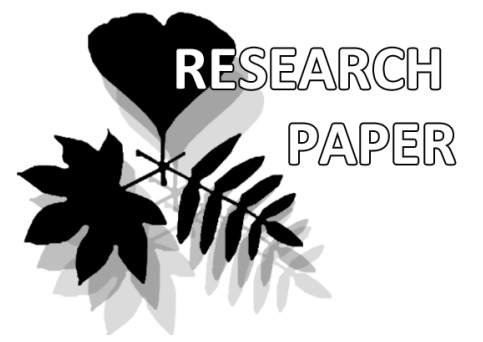

Vartika Singh $1, *$

e-mail: vartika.geo@gmail.com

Neelu Singh ${ }^{2}$

e-mail: neelu.singh0387@gmail.com

${ }^{1}$ Birbal Sahni Institute of Palaeobotany, 53 University Road, Lucknow 226007, India

${ }^{2}$ National Centre for Antarctic \& Ocean Research, Headland Sada, Vasco-da-Gama, Goa 403804, India

* corresponding author

Manuscript received: 07.08.2015

Review completed: 20.09.2015

Accepted for publication: 23.09.2015

Published online: 25.09 .2015

\section{Study of Entrained Antarctic Diatoms from the Southwest Indian Ocean}

\author{
Vartika Singh ${ }^{1, *} \&$ Neelu Singh ${ }^{2}$
}

\begin{abstract}
A B S T R A C T
The study of surface sediments collected at a depth of $4100 \mathrm{~m}$ from the Southwest Indian Ocean reveals presence of only biogenic siliceous morphotypes containing high amount of Antarctic diatoms. In addition the sediment also contains radiolarians, silicoflagellates, and sponge spicules in decreasing order of abundance after diatoms. The diatoms make about $70 \%$ of the total siliceous components and the assemblage is dominated by the Antarctic diatoms Thalassiosira lentiginosa (Janisch) Fryxell, Fragilariopsis kerguelensis (O’Meara) Hustedt and Eucampia antarctica (Castracane) Mangin. This study tries to look for the possible mechanism of entrained Antarctic diatoms from their place of origin, Southern Ocean to as far as the southern limit of Indian Ocean. The long range lateral transport has been viewed to have occurred under the influence of deep moving Antarctic bottom water from the Southern Ocean to the Indian Ocean. The role of lateral transport in deep ocean siliceous sediment re-deposition cannot be overlooked in the global ocean carbon transport.
\end{abstract}

K e y w o r d s : lateral transport, Antarctic Bottom Water, Thalassiosira lentiginosa, Fragilariopsis kerguelensis, Carbonate Compensation Depth, Southern Ocean

\section{P E 3 Ю M E}

Сингх В., Сингх Н. Исследование диатомей Юго-Западного Индийского океана, принесенных из Антарктики. Исследование поверхностных отложений с глубины 4100 м юго-западной части Индийского океана показало преобладание в осадках биогенных кремнистых морфотипов, содержащих большое количество антарктических диатомовых водорослей. Кроме того, осадки содержат также радиолярии, силикофлагелцяты и спикулы губок в порядке убывания обилия после Аиатомовых водорослей. Аиатомеи состав яют около 70 \% от общего объема кремнистых компонентов, и в сообществе Аоминируют антарктические диатомеи Thalassiosira lentiginosa (Janisch) Fryxell, Fragilariopsis kerguelensis (O’Meara) Hustedt и Eucampia antarctica (Castracane) Mangin. Исследование представляет попытку поиска возможного механизма дальнего переноса антарктических диатомей от их места происхождения - Южного океана, до южной границы Индийского океана.

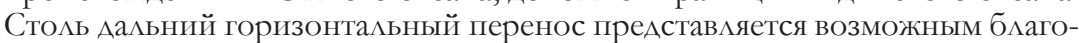
Ааря глубинным течениям придонных вод из Южного в Индийский океан. Горизонтальный перенос глубинными океаническими течениями кремнистых отложений не может быть проигнорирован в вопросах глобального транспорта углерода в океане.

К $\mathbf{\Lambda}$ ю че в ы е с $\mathbf{\Lambda}$ о в а: горизонтальный перенос, антарктические глубинные воды, Thalassiosira lentiginosa, Fragilariopsis kerguelensis, уровень карбонатной компенсации, Южный океан

Переведено редколмегией

\section{NTRODUCTION}

Diatoms form a major phytoplankton group in polar, and subpolar marine environments and are responsible for a greater percentage of organic carbon flux to the deep ocean (Buesseler 1998). The diatoms as phytoplankton are responsible for about $30-40 \%$ of primary production occurring at the ocean surface (DeMaster 2004). In the Southern Ocean (SO), diatoms contribute to about $75 \%$ of the primary productivity and thus play an important role in global carbon cycle (Treguer et al. 1995).

Diatoms are abundantly found in the cold nutrient rich regions and the upwelling zones where silicic acid is not a limiting factor (Crosta 2011). In other regions diatoms are outcompeted by carbonate and organic walled organisms having low nutrient requirement (Crosta 2011). SO is one such region, where there is a prominent opal zone and this ocean also acts as a major silica sink (Lisitzin 1985). High productivity is found beyond $50^{\circ} \mathrm{S}$, between Antarctic Polar Front $(\mathrm{PF})$ and winter sea ice edge owing to the upwelling of nutrient rich waters (Bareille et al. 1998, Fig. 1). The siliceous frustules are preserved readily beneath the Antarctic Circumpolar Current (AACC) (Armand et al. 2005). Diatoms are thus responsible for the organic carbon flux to the deep ocean. Primarily, the deep ocean biotic sedimen- 


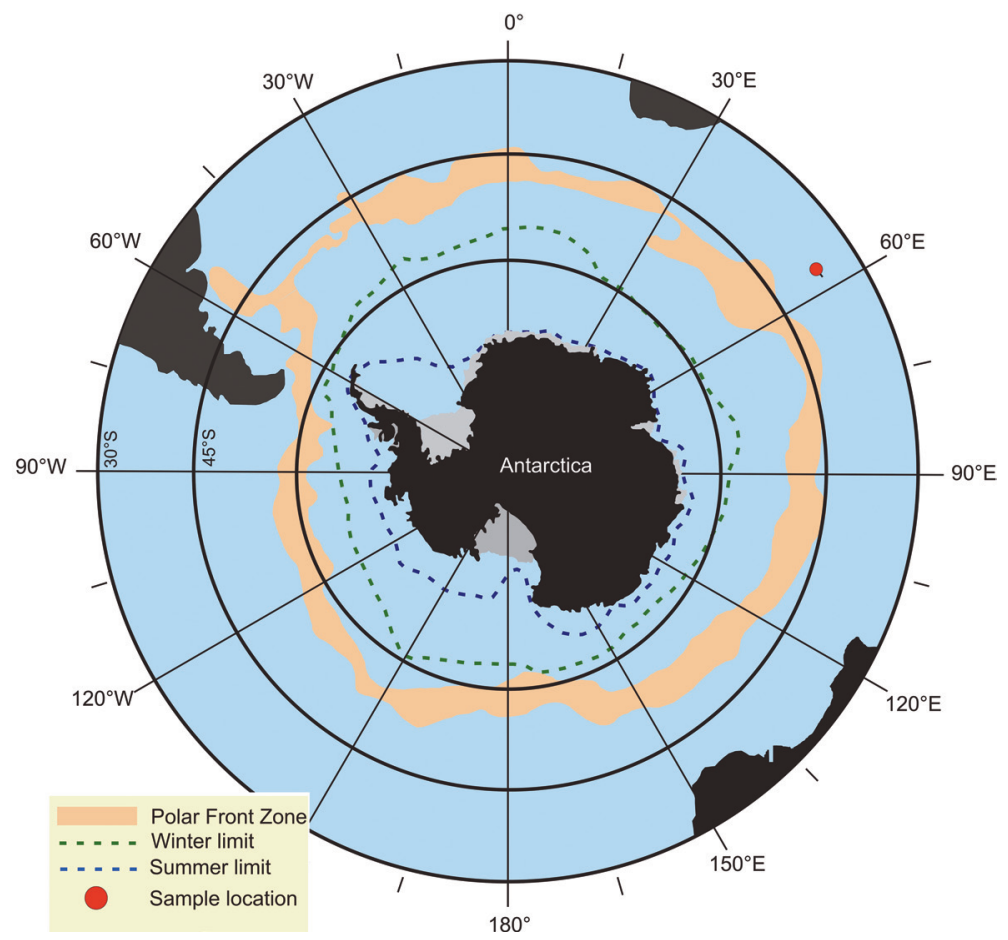

Figure 1 Position of Polar front, modern winter and summer sea-ice edges in the Southern Ocean (after Gersonde et al. 2005, Schweitzer 1995), and sampling area

tation is a factor of surface ocean productivity occurring in the photic zone (Crosta 2011). As a result, the deposition of high amounts of diatoms in the deep ocean reflects primary productivity at the ocean surface. Siliceous sedimentation occurs under the influence of several interacting factors, leading to enhanced burial of biogenic silica. The depth of undersaturated water column (carbonate compensation depth, CCD) controls the sedimentary processes of deposition (Hesse 1989) but preservation is facilitated by low temperatures.

The study is performed to trace the pathway of Antarctic diatoms deposited in the Southwest Indian Ocean (SWIO) (Fig. 1). The SWIO region is considered to have a complex oceanography owing to the influence of different ocean currents (Thomas et al. 2006). The deep and bottom waters from the Atlantic: North Atlantic Deep Water (NADW), Antarctic region: Antarctic Bottom Water (AABW) and Antarctic Intermediate Water (AAIW) follow the path through SW Indian ridge (Fig. 2). These water masses being part of the global thermohaline circulation play a crucial role in the climate system through the transport of heat and carbon (Broecker 1991).

The study site lies in the SWIO $\left(37^{\circ} \mathrm{S}, 57.3^{\circ}\right.$ E) (Fig. 1). Indian Ocean (IO) is landlocked to the north. This makes IO circulation a unique system displaying complex interaction between different water masses. Surface circulation in North Indian Ocean is affected by the seasonally reversing monsoon gyre and has no significant affect on the deep circulation of IO (Demopoulos et al. 2003). The hydrology of the deep SWIO region is mainly affected by three water masses moving northwards. AABW, which is a low salinity and high nutrient water mass, a water mass derived from NADW, having high salinity and low nutrients and the AAIW (Fig. 2) (Reid \& Lynn 1971, van Aken et al. 2004, Thomas et al. 2006). Indian Central Water (ICW) which forms in the subtropical gyre of the IO flows above these deep water masses (Thomas et al. 2006). NADW flows above the AABW at a depth of $\sim 2500 \mathrm{~m}$ and $40^{\circ} \mathrm{S}$ over the SW Indian Ridge to enter the Madagascar Basin following the South African continental margin (van Aken et al. 2004, Thomas et al. 2006). The flow of NADW and AAIW water masses is impeded by southward moving North Indian Deep Water (NIDW) from the north Indian Ocean and the Red Sea (Fig. 2).

\section{MATERIAL AND METHODS}

Surface sediments were collected during austral summer month of February during the SO expedition of 2010, using a grab sampler at depth of $4100 \mathrm{~m}$ at $37^{\circ} \mathrm{S}, 57.3^{\circ} \mathrm{E}$, from the eastern side of the Southwest Indian ridge (SWIR) (Fig. 1). Surface sediments were collected in order to understand the role of complex oceanographic conditions in sediment deposition.

The wet sediment samples were air dried at room temperature and processed separately for extraction of carbonaceous and siliceous contents. For the extraction of calcareous microfossils sediment slides were prepared without acid treatment (Katz 1978). Siliceous microfossils were extracted according Schrader (1973) and Koc-Karpuz \& Schrader (1990). The clay content of the sediment was removed by treating $3 \mathrm{~g}$ of the dried sediment with $5 \%$ calgon solution. Sediments were then treated with hydrogen peroxide and boiled for five minutes to remove unwanted organic debris. The samples were washed at every step by deionized water. The residue/resulting clean sediments

Figure 2 Schematic representations of water masses and their movement, depicting lateral sediment transport and deposition. Red dot represents location of sample and the presence of Carbonate Compensation Depth is represented by the broken green line at about $4000 \mathrm{~m}$ depth 
were then spread over the coverslip, dried and mounted on the slide using Canada balsam.

Detailed quantitative estimation of the siliceous content was carried out to study relative abundance of different constituents under the Leitz Laborlux D microsope. The relative abundance of diatoms was plotted after counting under the microscope. The quantitative estimation of diatoms followed (Schrader \& Gersonde 1978). Diatoms were considered intact, if more than $50 \%$ of the frustules were present. Diatom girdle bands were not included in the calculation of diatom relative abundance. At least 300 intact diatom frustules were counted at $\times 1000$ by vertical traverse movement of the slides. The diatoms having more than $0.2 \%$ relative abundance were considered in this study. Dominant Antarctic diatoms were identified up to species and subspecies level; identification of less abundant diatoms was done up to the generic level. Taxonomic identification of diatoms was done following handbooks (Hustedt 1958, Hasle 1965, Fenner et al. 1976, Johansen \& Fryxell 1985, Villareal \& Fryxell 1983, Fryxell 1991, Zielinski 1993). The relative abundance of each diatom species was calculated against the total diatom abundance to understand the origin of the dominating forms of the diatom assemblage (Fig. 3).

\section{RES U LT S}

The recovered sediments are mostly biogenic in nature consisting of only siliceous microfossils (diatoms, radiolarians, silicoflagellates and few sponge spicules) with complete absence of calcareous forms. Siliceous microfossils were dominated by diatoms, which accounted for about $60 \%$ of the total assemblage; radiolarians $30 \%$, silicoflagellates $8 \%$ and sponge spicules $2 \%$ (Fig. 4). The SWIO region diatoms have not been studied significantly. Siliceous sediments deposited in the SWIO at a depth of $4100 \mathrm{~m}$ contain large fraction of diatoms (Fig. 4). Only about $29 \%$ of the diatoms reflect tropical/subtropical ecological preference and a much higher proportion $(70 \%)$ of diatoms reflect polar/subpolar conditions (Fig. 3).

Recovered diatoms represent a low diversity and high abundance assemblage, indicated by the presence of 12 genera and 13 species. Abundance is represented by very high percentage of Thalassiosira lentiginosa, which alone constituted $37 \%$ of the total diatom population, followed by Fragilariopsis kerguelensis and Eucampia antarctica having abundance of $16 \%$ and $12 \%$, respectively (Fig. 3). These three diatom morphotypes make about $65 \%$ of the total diatom assemblage and are thus considered as key forms of the assemblage. The recovered diatoms have been classified on the basis of the ecological preference they show in their place of origin (SO) and fall under two categories; Antarctic (Open Ocean and sea ice related diatoms) and subAntarctic to sub-tropical zone diatoms (Fig. 3).

\section{Open Ocean (Southern Ocean) Diatoms}

Thalassiosira lentiginosa and Fragilariopsis kerguelensis are open ocean dwelling forms of the SO
(Crosta et al. 2005). Highest abundance of T. lentiginosa is reported from the permanent Open Ocean zone to the Polar Front zone (Fig. 1) Jousé et al. 1962, Kozlova 1966, Kozlova \& Mukhina 1967, Abbott 1973, Donahue 1973, Fenner et al. 1976, DeFelice \& Wise 1981, Zielinski \& Gersonde 1997, Crosta et al. 1998). The abundance decreases in sub Antarctic and subtropical zone (Crosta et al. 2005).

F. kerguelensis is endemic to $\mathrm{SO}$ and is a dominating form of the diatom assemblage in the Open Ocean zone south of the Polar Front to the Subtropical Front (Fig. 1), which is the northern boundary of its distribution (Crosta et al. 2005, Froneman et al. 1995, Hasle 1976, Semina 2003). This species prefers warm waters $\left(1-7^{\circ} \mathrm{C}\right.$ of Sea Surface Temperature, SST) of the Antarctic and sub-Antarctic realms, beyond which its amount decreases both by increasing and decreasing temperatures towards north and south respectively (Crosta et al. 2004).

\section{Sea-ice related Diatoms}

Eucampia antarctica is represented by two varieties E. antarctica var. recta and E. antarctica var. antarctica showing different growth habits. E. antarctica var. recta dominates the assemblage. E. antarctica var. recta forms straight chains whereas E. antarctica var. antarctica forms spiralling chains due to asymmetric valves. These two varieties produce less silicified forms during the summer and highly silicified forms during winter. The var. antacrtica is distributed in subpolar regions and var. recta occupy cold water masses around continuously moving sea-ice close to the Antarctic continental shelf during summer (Kaczmarska et al. 1993). The length of the chain is determined by the ratio of terminal to intercalary valves. Eucampia antarctica produces morphologically different summer and winter stages, different terminal and intercalary valves and also different warm and cold varieties. This ratio can be used to study sea-ice extent (Kaczmarska et al. 1993, Fryxell 1991).

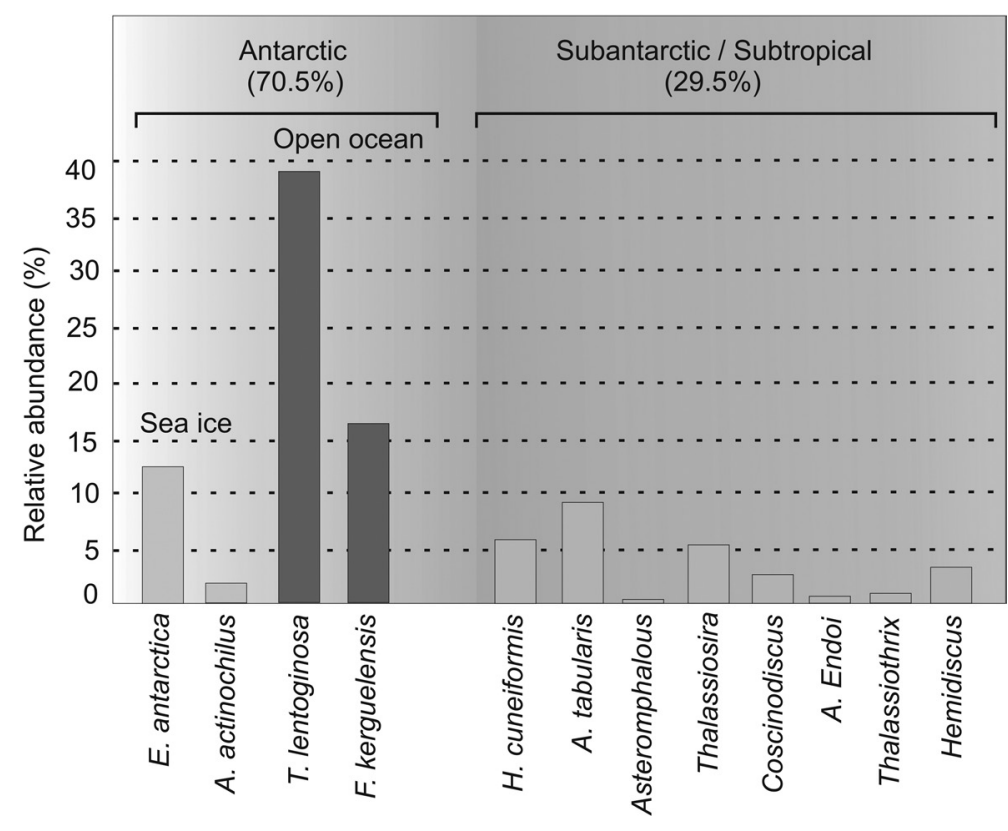

Figure 3 Relative abundance of diatoms depicts abundance of Antarctic diatoms. Green and blue bars represent sea ice and open ocean indicator diatoms, respectively in the Southern Ocean 
Actinocyclus actinochilus (Ehrenberg) Simonsen has a relative abundance of about $2 \%$. A. actinochilus is said to be confined to the south of the Polar Front (Donahue 1973, Defelice \& Wise 1981, Zielinski \& Gersonde 1997, Semina 2003, Armand et al. 2005) (Fig. 2). Presence of A. actinochilus is also reported from north of Polar Front $(\mathrm{PF})$ but there is a lack of abundance data. However, maximal abundance of $4.7 \%$ has been described by Zielinsky \& Gersonde (1997) in the south Atlantic sector with a summer SST range between -2 and $2^{\circ} \mathrm{C}$. A. actinochilus has been considered as cool water Antarctic species limited to the north by the PF and maximum winter sea ice edge (Armand et al. 2005) (Fig. 2).

\section{Subantarctic-subtropical Diatoms}

Hemidiscus cuneiformis Wallich and Azpeitia tabularis (Grunow) G. Fryxell \& P.A. Sims have relative abundances of $4.8 \%$ and $0.8 \%$ respectively. These have been grouped under the Subantarctic Zone group (SAZ) of Crosta et al. (2004), represented by warm water species. H. cuneiformis is a Tropical/Subtropical, warm water diatom (Hasle \& Syvertsen 1996, Semina 2003, Romero et al. 2005) and has been considered as a rare element of Arabian Sea and Indian Ocean diatom assemblages (Simonsen 1974). This species has also been reported from the surface sediments of warm-temperate waters of Pacific, Indic and Atlantic oceans (Fryxell et al. 1986, Romero et al. 2005). Highest abundances are associated with $>11^{\circ} \mathrm{C}$ SST. Azpeatia tabularis attains maximum abundance north of the PF in warm SST of SO (Romero et al. 2005). The other recovered diatoms such as Thalassiosira sp., Coscinodiscus sp., Azpeitia endoi Kanaya, Asteromphalus sp. are also indicative of tropical and subtropical conditions.

\section{DISCUSSION AND CONCLUSIONS}

The SWIO region diatoms have not been studied significantly. The presence alongwith the relative abundance of diatoms has been scarcely studied from the SWIO region. Siliceous sediments deposited in the SWIO at a depth of $4100 \mathrm{~m}$ contain large fraction of diatoms (Fig. 2). Total siliceous content comprises of diatoms $>$ radiolarians $>$ silicoflagellates $>$ sponge spicules in order of abundance (Fig. 4). A much greater proportion $(70 \%)$ of diatoms reflects polar/subpolar conditions, with only $29 \%$ of the diatoms reflecting tropical/subtropical ecological preference (Fig. 4). Therefore, a significant part of the recovered diatom assemblage does not correspond to the ocean surface conditions, supporting rich siliceous biota. The southwestern region of IO shows low nutrient condition (Fig. 2) in the photic zone due to absence of any land source and oceanic upwelling. The deposition of diatoms in the deep SWIO region has been noted to have occurred below CCD following lateral transport (Fig. 2).

Among the Antarctic diatom $65 \%$ of the total recovered diatoms are displayed by three dominant Antarctic diatoms Thalassiosira lentiginosa (L) (37\%), Fragilariopsis kerguelensis (K) $(16 \%)$ and Eucampia antarctica (12\%) (Fig. 3). These three forms are reported to be dominant in the SO sediments and form about $90 \%$ of the total diatom assemblage (Shemesh 1989). The two dominant Open Ocean diatom species

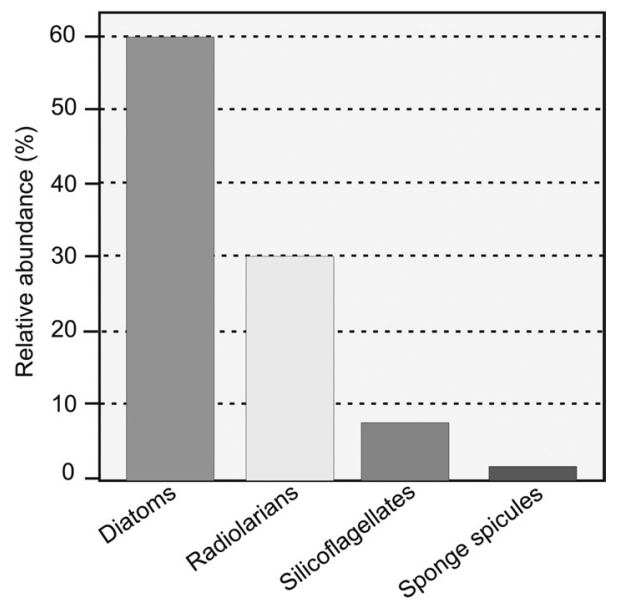

Figure 4 Relative abundance of total siliceous remains

(T. lentiginosa, F. kerguelensis) form almost $50 \%$ of recovered diatoms. Antarctic diatom assemblage contains diatoms having different ecological preferences in the SO. Key diatoms T. lentiginosa and F. kerguelensis $(\mathrm{L}+\mathrm{K}=52 \%)$ are the main open ocean indicators, E. antarctica, Hemidiscus cuneiformis Wallich and Actinocyclus actinochilus (Ehrenberg) Simonsen $(22 \%)$ on the other hand indicate sea-ice extent. Thus, the assemblage contains diatoms depicting mixed ecological preferences in terms of SST and sea-ice cover. This mixed diatom assemblage of SWIO signifies sediment redeposition.

The deposition of biogenic siliceous matter in the SWIO occurs under the complex physical/oceanographic, chemical and biological processes acting together. Sedimentation of diatoms / diatom flux to the sea floor is controlled by sedimentation type (whether individual valves or aggregates trapped in the faecal pellets) (Schrader 1971, Smetacek 1985, von Bodungen et al. 1986) lateral transport (Leventer 1991) and dissolution in the water column and at the water-sediment interface (Kamatani et al. 1988, Shemesh et al. 1989).

The distribution of diatoms in surface sediments of SWIO is related to secondary process of lateral transport representing allocthonous sediment deposit. The possible pathway followed during lateral movement/entrainment of Antarctic diatoms towards the Indian Ocean has been envisaged. $\mathrm{AABW}$ is a major water mass that originates from $\mathrm{SO}$ and flows northwards as a bottom current. AABW leaves the AACC and enters into the Indian Ocean from SE through the SWIR flowing below $3800 \mathrm{~m}$ depth (Fig. 2) and fills the IO in the Madagascar basin and gaps in the SWIR (Demopoulos et al. 2003, Thomas et al. 2006). During the movement, AABW from the SO region scours SO sediments rich in Antarctic diatoms which is transported via deep ocean circulation to the SWIO and deposited near the SWIR. The SWIR acts as a barrier to the flow of AABW facilitating the deposition of south polar siliceous sediments. The deposition of entrained sediments consisting entirely of biogenic siliceous matter is attributed to the north ward flowing deep ocean circulation system of SO.

Similar mechanism of deposition of entrained Antarctic diatoms has been reported by Dizileau et al. (2000), from the Kerguelen Plateau. The occurrence of SO diatoms in subtropical zone surface sediments outside SO has been 
reported form southeast Atlantic, glacial sediments of the Benguela upwelling system (Crosta et al. 2005). The diatoms E. antarctica and A. actinochilus were reported from the temperate south Atlantic of Pleistocene age from the north-eastern Argentine Basin located at $37^{\circ} \mathrm{S}$ and $35^{\circ} \mathrm{W}$, at $5000 \mathrm{~m}$ depth (Fenner 1977). This presence was attributed to the transport by AABW (Burckle \& Stanton 1975). DeFelice \& Wise (1981) also found E. antarctica in the sediment cores of the south Atlantic from the Agulhas Basin. Abott found E. antarctica abundantly throughout the Subantarctic in the southeast Indian Ocean. Dezileau et al. (2000) studied sediment redistribution around Southeast Indian Ridge and Kerguelen plateau stressing on the role of AABW.

Shemesh et al. (1989) have demonstrated that dissolution also acts as an important factor in the temporal and spatial variations of sedimentary diatom assemblages of the SO. They suggested that Holocene SO sediments show increase in opal preservation towards high latitudes. Opal is well preserved in SE Indian Ocean; preservation decreases in Southern Atlantic \& SWIO while in SE Pacific it is poorly preserved, based on their Preservation Index data.

The recovered sediments contain only siliceous remains and thus, point towards deposition below the Carbonate Compensation depth in the SWIO. In the Indian Ocean CCD is known to be located at an intermediate depth between carbonate rich Atlantic and carbonate poor Pacific oceans (Demopoulos et al. 2003). The carbonate critical depth is deepest in the equatorial IO and shoals to $3900 \mathrm{~m}$ between $50^{\circ} \mathrm{S}$ and $60^{\circ} \mathrm{S}$. The study thus substantiates the presence of CCD at $4100 \mathrm{~m}$ at $37^{\circ} \mathrm{S}$ latitude in the SWIO.

The $231 \mathrm{~Pa}$ water mass tracer profile study conducted in the SWIO by Thomas et al. 2006 indicates that when water mass moves above siliceous productivity rich ocean zone, $231 \mathrm{~Pa}$ experiences a loss. Such a loss was observed in the water masses of AABW and AAIW in the SWIO, because these water masses moved through the opal belt of SO. However, NADW showed high 231 Pa probably because this water mass did not flow through high siliceous productivity zone. This further strengthens the idea of siliceous sediment transport and deposition by AABW.

The biogenic siliceous sediment deposition even though acted upon by several complex processes in this region displays a significant role and influence of AABW. This study of Antarctic diatoms recovered from the Indian Ocean provides an account of lateral transport brought about by the deep ocean circulation and sedimentation. This represents a secondary assemblage formed as a result of transport of already deposited sediment of the SO which eventually gets deposited in the SWIO.

\section{ACKNOWLEDGEMENTS}

We gratefully acknowledge the Director, Birbal Sahni Institute of Palaeobotany for providing continuous support, encouragement and all the basic facilities to carry out this work (Ref: BSIP/RPCC/2012-110). We also thank the Director, National Centre for Antarctic \& Ocean Research, Goa, for providing all the help in carrying out collaborative research work. Late Prof. Valentine Krasilov had been a source of motivation to carry out this work, while his stay in BSIP. The constant help, guidance and support provided by Dr. Sophia Barinova is also thankfully acknowledged. We also thank the two anonymous reviewers for providing valuable suggestions that significantly improved the manuscript.

\section{LITERAT URE CITED}

Abbott, W.H.J. 1974. Temporal and spatial distribution of Pleistocene diatoms from the southeast Indian Ocean. Nova Hedwigia Beibefte 25:291-346.

Abbott, W.H.J. 1973. Vertical and lateral patterns of diatomaceous ooze found between Australia and Antarctica. PhD Thesis, Department of Geology, University of South Carolina, USA.

Armand, L., X. Crosta, O. Romero \& J.J. Pichon 2005. The biogeography of major diatom taxa in Southern Ocean sediments: 1 . Sea ice related species. Palaeogeography, Palaeoclimatology, Palaeoecology 223(1-2):93-126.

Bareille, G., M. Labracherie, P. Bertrand, L. Labeyrie, G. Lavaux \& M. Dignan 1998. Glacial-interglacial changes in the accumulation rates of major biogenic components in Southern Indian Ocean sediments. Journal of Marine Systems 17:527-539.

Broecker, W.S. 1991. The great ocean conveyor. Oceanography 4:79-89.

Buesseler, K.O. 1998. The decoupling of production and particulate export in the surface ocean. Global Biogeochemical Cycles 12:297-310.

Burckle, L.H \& D. Stanton 1975. Distribution of displaced Antarctic diatoms in the Argentine Basin. In: Third Symposium on Recent and Fossil Marine Diatoms (Simonsen, R., ed.), pp. 283-292, Kiel, F.R. Germany.

Crosta, X. 2011. Marine diatoms in Polar and sub-polar environments and their application to late Pleistocene palaeoclimate reconstruction. In: IOP Conf, IOP Conf. Series: Earth and Environmental Science 14, pp. 1-18.

Crosta, X., J.J. Pichon \& L.H. Burckle 1998. Application of modern analog technique to marine Antarctic diatoms: reconstruction of the maximum sea ice extent at the last glacial maximum. Paleoceanography 13(3):284-297.

Crosta, X., O. Romero, L. Armand \& J.J. Pichon 2005. The biogeography of major diatom taxa in Southern Ocean sediments: 2. Open ocean related species. Palaeogeography, Palaeoclimatology, Palaeoecology 223:66-92.

Crosta, X., A. Sturm, L. Armand \& J.J. Pichon 2004. Late Quaternary sea-ice history in the Indian sector of the Southern Ocean as recorded by diatom assemblages. $M a$ rine Micropaleontology 50:209-223.

Defelice, D.R \& S.W. Wise 1981. Surface lithofacies, biofacies, and diatom diversity patterns as models for delineation of climatic change in the Southeast Atlantic Ocean. Marine Micropaleontology 6:29-70.

DeMaster, D.J. 2004. The diagenesis of biogenic silica: Chemical transformations occurring in the water column, seabed, and crust. In: Treatise of geochemistry (Mackenzie, F.T., ed.), 7, pp. 87-98, Elsevier, Oxford.

Demopoulos, A.W.J., C.R. Smith \& P.A. Tyler 2003. Ecology of the deep Indian Ocean floor. In: Ecosystems of the World 28: Ecosystems of the Deep Ocean (Tyler, P.A., ed.), pp. 219-237, Elsevier, Amsterdam.

Dezileau, L., G. Bareille, J.L. Reyss \& F. Lemoine 2000. Evidence for strong sediment redistribution by bottom currents along the southeast Indian ridge. Deep-Sea Research I 47:1899-1936.

Donahue, J.G. 1973. Distribution of planktonic diatoms in surface sediments of the Southern South Pacific. In: $\mathrm{Ma}$ rine Sediments of the Southern Ocean (Goodell, H.G., ed.), pp. 9-18, Amer. Geophysical Soc., Antarctic Map Folio Ser. 
Fenner, J. 1977. Cenozoic diatom biostratigraphy of the equatorial and southern Atlantic Ocean. In: Initial reports of the deep-sea drilling project 39 (Perch-Nielsen, K., Supko, P.R. et al., eds.), pp. 491-623, Government Printing Office, Washington DC, U.S.

Fenner, J., H.J. Schrader \& H. Wienigk 1976. Diatom phytoplankton studies in the Southern Pacific Ocean, composition and correlation to the Antarctic Convergence and its paleoecological significance. In: Initial reports of the deep-sea drilling project 35 (Hollister, C.D., Craddock, C. et al., eds.), pp. 757-813, , Government Printing Office, Washington DC, U.S.

Froneman, P.W., R. Perissinotto, C.D. McQuaid \& R.K. Laubscher 1995. Summer distribution of net phytoplankton in the Atlantic sector of the Southern Ocean. Polar Biology 15:77-84.

Fryxell, G.A., A.K.S.K. Prasad \& P.A. Fryxell 1989. Eucampia antarctica (Castracane) Mangin (Bacillariophyta): complex nomenclatural taxonomic history. Taxon 38:638-649.

Fryxell, G.A. 1991. Comparison of winter and summer growth stages of the diatom Eucampia antarctica from the Kerguelen Plateau and south of the Antarctic Convergence Zone. In: Proceedings of Ocean Drilling Program, Scientific Results, 119 (Barron, J., Larsen, B. et al., eds.), pp. 675685, Ocean Drilling Program, College Station, TX.

Fryxell, G.A., P.A. Sims \& T.P. Watkins 1986. Azpeitia (Bacillariophyceae): related genera and promorphology. American Society of Plant Taxonomy 13:74.

Gersonde, R., X. Crosta, A. Abelmann \& L.K. Armand 2005. Sea surface temperature and sea ice distribution of the last glacial. Southern Ocean - a circum-Antarctic view based on siliceous microfossil records. Quaternary Science Reviews 24:869-896.

Hasle, G.R. 1965. Nitzschia and Fragilariopsis species studied in the light and electron microscope: III The genus Fragilariopsis. Skrifter utgitt av det Norske Videnskaps-Akademi 18:1-45.

Hasle, G.R. 1976. The biogeography of some marine diatoms. Deep-Sea Research 23:319-338.

Hasle, G.R. \& E.E. Syvertsen 1996. Marine diatoms. In: Identifying Marine Diatoms and Dinoflagellates (Tomas, C.R., ed.), pp. 5-385, Academic Press, San Diego.

Hesse, R. 1989. Silica diagenesis: origin of inorganic and replacement cherts. Earth-Science Reviews 26:253-284.

Hustedt, F. 1958. Diatomeen aus der Antarktis und dem Südatlantik. Reprinted from: Deutsche Antarktische Expedition 19838/1939. Band II. Geographische-Kartographische Anstalt, ss. 191, Mundus, Hamburg.

Ito, T., M. Woloszyn \& M. Mazloff 2010. Anthropogenic carbon dioxide transport in the Southern Ocean driven by Ekman flow. Nature 463:80-83.

Johansen, J.R. \& G.A. Fryxell 1985. The genus Thalassiosira (Bacillariophyceae): studies on species occurring south of the Antarctic Convergence. Phycologia 24(2):155-179.

Jouse, A.P., G.S. Koroleva \& G.A. Nagaeva 1962. Diatoms in the surface layer of sediment in the Indian sector of the Antarctic. Trudy Instituta Okeanologii Akademii Nauk SSSR 61:20-91 (in Russian). [Жузе А.П., Королева Г.С., Нагаева Г.А. 1962. Аиатомовые водоросли в поверхностном слое Аонных осадков Индийского сектора Антарктики // Труды института океанологии АН СССР. T. 61. C. 1-92].

Kaczmarska, I., N.E. Barbrick, J.M. Ehrman \& G.P. Cant 1993. Eucampia index as an indicator of the Late Pleistocene oscillations of the winter sea-ice extent at the Leg 119 Site 745B at the Kerguelen Plateau. Hydrobiologia 269/270:103-112.
Kamatani, A., N. Ejiri \& P. Treguer 1988. The dissolution kinetics of diatom ooze from the Antarctic area. Deep-Sea Research 35(7): 1195-1203.

Katz, B.J. 1978. Preparation of calcareous nannofossil assemblages for chemical examination. Journal of Paleontology 52:497-500.

Koc-Karpuz, N. \& H. Schrader 1990. Surface sediment diatom distribution and Holocene paleotemperature variations in the Greenland, Iceland and Norwegian Sea. Paleoceanography 5(4):557-580.

Kozlova, O.G. 1966. Diatoms of the Indian and Pacific sectors of the Antarctic. Israel Program for Scientific Translations, p. 185 (pl. I-VI), National Science Foundation, Washington, D.C.

Kozlova, O.G. \& V.V. Mukhina 1967. Diatoms and silicoflagellates in suspension and floor sediments of the Pacific Ocean. International Geology Review 9(10):1322-1342.

Leventer, A. 1991. Sediment trap diatom assemblages from the northern Antarctic Peninsula region. Deep-Sea Research 38:1127-1143.

Lisitzin, A.P. 1985. The silica cycle during the last ice age. Palaeogeography, Palaeoclimatology, Palaeoecology 50:241-270.

Mantyla, A.W. \& J.L. Reid 1995. On the origins of deep and bottom waters of the Indian Ocean. Journal of Geophysical Research 100:2417-2439.

Ragueneau, O., P. Tréguer, A. Leynaert, R.F. Anderson, M.A. Brzezinski, D.J. DeMaster, R.C. Dugdale, J. Dymond, G. Fischer, R. François, C. Heinze, E. Maier-Reimer, V. Martin-Jézéquel, D.M. Nelson \& B. Quéguiner 2000. A review of the Si cycle in the modern ocean: Recent progress and missing gaps in the application of biogenic opal as a paleoproductivity proxy. Global and Planetary Change 20:317-365.

Reid, J.L. \& R.J. Lynn 1971. On the influence of the Norwegian-Greenland and Weddell seas upon the bottom waters of the Indian and Pacific Oceans. Deep-Sea Research I. 18: 1063-1088.

Romero, O.E., L.K. Armand, X. Crosta \& J.J. Pichon 2005. The biogeography of major diatom taxa in Southern Ocean surface sediments: 3. Tropical/Subtropical species. Palaeogeography, Palaeoclimatology, Palaeoecology 223(1-2): 49-65.

Sabine, C.L., R.A. Feely, N. Gruber, R.M. Key, K. Lee, J.L. Bullister, R. Wanninkhof, C.S.Wong, W.R.W. Douglas, B. Tilbrook, F.J. Millero, T.H. Peng, A. Kozyr, T. Ono \& A.F. Rios 2004. The oceanic sink for anthropogenic $\mathrm{CO}_{2}$. Science 305:367-371.

Schrader, H.J. 1973. Cenozoic diatoms from the northeast Pacific, Leg 18. Proceedings of the Ocean Drilling Program, Initial Reports 18: 673-797, U.S. Government Printing Office, Washington, DC.

Schrader, H.J. 1971. Fecal pellets: Role in sedimentation of pelagic diatoms. Science 174:55-77.

Schrader, H.J. \& R. Gersonde 1978. Diatoms and silicoflagellates. Utrecht Micropaleontology Bulletin 17:129-176.

Schweitzer, P.N. 1995. Monthly averaged polar sea-ice concentration. US Geological Survey Digital Data Series, Virginia.

Semina, H.J. 2003. SEM-studied diatoms of different regions of the World Ocean. Iconographia Diatomologica 10: 1-362.

Shemesh, A., L.H. Burckle \& P.N. Froelich 1989. Dissolution and preservation of Antarctic diatoms and the effect on sediment thanatocenoses. Quaternary Research 31: 288-308.

Simonsen, R. 1974. The diatom plankton of the Indian Ocean Expedition of R/V Meteor 1964-1965. MeteorForschung Ergebenisse Der Biology 19:1-107. 
Smetacek, V.S. 1985. Role of sinking in diatom life-history cycles: Ecological, evolutionary and geological significance. Marine Biology 84: 239-251.

Thomas, A.L., G.M. Henderson \& F. Robinson 2006. Interpretation of the $231 \mathrm{~Pa} / 230 \mathrm{Th}$ paleocirculation proxy: New water-column measurements from the southwest Indian Ocean. Earth and Planetary Science Letters 241: 493-504.

Tréguer, P., D.M. Nelson, A.J. van Bennekom, D.J. DeMaster, A. Leynaert \& B. Quéguiner 1995. The silica balance in the world ocean: A reestimate. Science 268:375-379.

van Aken, H.M., H. Ridderinkhofa \& W.P.M. de Ruijter 2004. North Atlantic deep water in the south-western Indian Ocean. Deep-Sea Research I 51:755-776.

Villareal, T.A. \& G.A. Fryxell 1983. The Genus Actinocyclus (Bacillariophyceae): frustules morphology of $A$. sagittulus sp. nov. and two related species. Journal of Phycology 19: 266-452.

von Bodungen, B., V. Smetacek, M.M. Tilzer \& B. Zeitzschel 1986. Primary production and sedimentation during spring in the Antarctic Peninsula region. Deep-Sea Research I. 33:177-194.

Zielinski, U. 1993. Quantitative estimation of palaeoenvironmental parameters of the Antarctic surface water in the Late Quaternary using transfer functions with diatoms. Berichte zur Polarforschung 126:1-148.

Zielinski, U. \& R. Gersonde 1997. Diatom distribution in Southern Ocean surface sediments (Atlantic sector): implications for paleoenvironmental reconstructions. Palaeogeography, Palaeoclimatology, Palaeoecology 129:213-250.

\section{Vartika Singh \& Neelu Singh:}

\section{नैनं छन्दिन्ता शित्र्राणा नैनं दहता पावक: न चैनं क्लेदयन्त्यापो न शोषयता मारुतः}

The soul can never be cut into pieces by any weapon, nor can he be burned by fire, nor moistened by water, nor withered by the wind.

Shlok 2.23, Bhagavad-gita (in Sanskrit)

Prof. Valentin A Krasilov has made an immense contribution to the world of Palaeobotany and Botany alike. He will always be remembered through his work. The list of his achievements and contributions is too long to be quoted here. Starting from his work on floristic evolution and fossil plants of Russia, this later on expanded to Kazakhstan, Mongolia, Mali, Israel, Lebanon and also India. He was bestowed with the indomitable insight and power to unfold the secrets of Mother Nature. He gave a new dimension to the understanding of origin and evolution of Angiosperms. Plant-insect coevolution is another remarkable example of his scientific aptitude. His progressive thoughts took him from mega to micro and molecular levels in his quest for knowledge.

Prof. Krasilov was not just a good researcher but was also a good teacher and above all a good soul and a nice human being. Today I recall the incident when I first met Prof. during his visit to India and my Institute Birbal Sahni Institute of Palaeobotany, Lucknow. As he was visiting the different laboratories of the institute he came to see the Polar Research Lab where I worked, I stood in respect to meet Prof. Krasilov, he asked about my work and research interest. I told him that I worked on the diatoms, dinoflagellates and organic matter of the Polar sediments. He then introduced me to his wife Dr. Sophia Barinova who was accompanying him and told me that she also studies diatoms and I could learn from her. In this very small interaction he tried to help me to learn techniques from his wife. Such was his magnificent attitude towards everyone he came across. He was a man of wisdom. Since then he and his wife always extended their help and support to me as a young researcher. During his visit to my institute I saw him working from early in the morning till late evenings. He was passionate researcher. I pray to God to rest his soul in eternal peace.

His work is immortal and he will remain alive through is work as an immortal soul forever and ever. 